\title{
Carboxyhemoglobin Detection in the Periorificial Tissues as an Accurate Method for Identifying the Gunshot Entrance Wound
}

\author{
CAMELIA-OANA MURESAN ${ }^{1}$, ROXANA ZAVOI ${ }^{2 *}$, VERONICA CIOCAN ${ }^{1 *}$, RALUCA DUMACHE ${ }^{1}$, RAMONA PARVANESCU ${ }^{3}$, \\ ALEXANDRA ENACHE ${ }^{1}$ \\ ${ }^{1}$ Victor Babes University of Medicine and Pharmacy Timisoara,Department of Legal Medicine, Bioethics, Medical Ethics and \\ Medical Law, 2 Eftimie Murgu Sq., 300041, Timisoara, Romania \\ 2 University of Medicine and Pharmacy Craiova, Department of Legal Medicine, 2 Petru Rares Str, 200349, Craiova, Romania \\ ${ }^{3}$ Doctoral School of Victor Babes University of Medicine and Pharmacy Timisoara, 2 Eftimie Murgu Sq., 300041, Timisoara, \\ Romania
}

\begin{abstract}
One of the main objectives of the forensic expertise in gunshot injuries is establishing the direction of the shooting. The firststep of the process is represented by studying the macroscopic differences in the morphology of the entrance and exit wounds, which in most cases suffice for the differential diagnosis between entrance and exit wound. In some cases, making the difference by using morphology alone is not possible, because the two wounds may present common or peculiar features. In these cases, analytical investigations can help in solving this important aspect of the case investigation. The detection of carboxyhemoglobin (COHb) in the perilesional tissues is one of the differentiation criteria between entry and exit wound. In some cases of short range shooting included in our study group, we determined the $\mathrm{COHb}$ concentration in blood sampled from the entrance wound. $\mathrm{COHb}$ values ranged between $10 \%$ and $60 \%$. Given the known chemical stability of $\mathrm{COHb}$, its determination can also prove useful in the examination of putrefied bodies, where the morphology of the gunshot wounds is more or less altered, depending on the stage of putrefaction.
\end{abstract}

Keywords: gunshot injuries, entrance wound, carboxyhemoglobin

One of the main objectives of forensic expertise in cases of death by firearms is establishing the direction of the shot [1], which can be appreciated depending on the location of the entrance and the exitwound [2]. In forensic medicine the morphology of gunshot injuries plays an important role [3]. In a vast majority of cases, the morphological features of gunshot injuries allow the macroscopic differentiation between the entrance and the exit w ound [1]. The distinction between the entrance and the exit wound based on morphology takes in consideration the shape, the size [4], the margins of the wound and the presence or lack of additional elements (abrasion ring, stippling, searing, soot soiling) [5]. The entrance wound is a round or oval area with lack of tissue, while the exit wound has an irregular shape with tearing effect. There is also a difference in size between the entrance and exit wound - the entrance wound is usually smaller than the exitwound. The gunshotresidue is present only at the entrance wound [4].

There are also cases in which the aspect of the gunshot injuries is non-specific, so the direction of the shot cannot be established with certainty [2]. Atypical entrance wounds may develop due to anatomical or ballistic causes, such as the presence of a flat bone immediately beneath the skin, a projectile encountering an intermediate target or the use of a projectile smaller than the weapon size [6]. If a bullet is deformed before entering the target, the configuration of the injury may be bizarre and the wound configuration may resemble the bullet configuration [7]. In such cases, complementary investigations are needed [8]. When a shotgun is fired, flames and hot gas follow the shot. These gas is a mixture of nitrogen oxides, carbon dioxide, hot air, carbon monoxide (CO) and other compounds [9]. Carbon monoxide is a colorless, odorless and insipid gas produced by the incomplete combustion of hydrocarbs, when carbon binds with oxygen [10]. Carbon monoxide binds rapidly to hemoglobin, leading to the formation of carboxyhemoglobin [11], which gives the blood in the periorificial tissues a bright red color [12]. The affinity of hemoglobin for carbon monoxide is 210 times higher than for oxygen. [13]. Toxicological examination of the blood sampled from the periorificial tissues allows the differentiation between the entrance and exitwound based on the $\mathrm{COHb}$ concentration levels in the two injuries [8], especially in cases where putrefaction changes their morphological characteristics [11].

Microscopic examination of tissues harvested from the entrance wound may reveal the presence of soot or pow der tattooing [1].

\section{Experimental part}

Materials and methods

In a retrospective study that we conducted at the Institute of Forensic Medicine Timisoara between 2000 and 2018 , we identified 21 cases of deaths due to gunshot injuries. In most cases, the entrance and the exit wound were identified based on their morphological characteristics. In 4 cases of short range shooting, the $\mathrm{COHb}$ concentration in blood sampled from the entrance wound neighboring tissues was determined. In one case we also determined the $\mathrm{COHb}$ concentration in blood sampled from the exit wound.

The carboxyhemoglobin concentration was determined by the spectroscopic method. The Oxyhemoglobin $\left(\mathrm{HbO}_{2}\right)$ and $\mathrm{COHb}$ absorption spectra in the visible field are each formed of two similar stripes, but slightly displaced one from the other one. By adding a reducing agent, $\mathrm{HbO}_{2}$ is reduced to hemoglobin, which leads to the disappearance of its two characteristic stripes and the appearance of the

*email: roxanazavoi@yahoo.com, Phone: 0251410601; veronica.luta@gmail.com, Phone: 0256466001 
hemoglobin absorption stripe, known as the Stokes stripe. Under the same conditions, $\mathrm{COHb}$ retains its two stripes.

The sampled blood is diluted with distilled water in a 1:100 ratio and filtered; the filtrate is divided in two portions, which are examined with the spectroscope. The first filtered portion, examined as such, has a characteristic spectrum for $\mathrm{HbO}_{2}$, namely two dark stripes: the first one, narrower, in the yellow area, along Frauenhofer's $D$ line, with a peak at $578 \mathrm{~nm}$ and limits at 587- $568 \mathrm{~nm}$ and the other one, wider, in the green area, next to $\mathrm{E}$ line, with a maximum at $542 \mathrm{~nm}$ and limits at $552-527 \mathrm{~nm}$. The second portion of the filtrate is treated with a few drops of $10 \%$ ammonium polysulfide or a few crystals of sodium hydrosulfite and, after a few minutes, examined with the spectroscope. The characteristic spectrum of reduced hemoglobin - because $\mathrm{HbO}_{2}$ gave the oxygen to the reducing agent - is formed by a single dark stripe (Stokes stripe); the margins of the Stroke stripe are not perfectly delimited, it is located between the $D$ and $E$ lines, has a maximum of $555 \mathrm{~nm}$ and limits at $565-545 \mathrm{~nm}$.

If the blood contains $\mathrm{CO}$, two oxyhemoglobin-like stripes can be observed on the spectroscope, but slightly shifted in the green field with the maxima at $570 \mathrm{~nm}$ and $539 \mathrm{~nm}$. When a reducing agent is added, these two stripes do not disappear to form the Stokes stripe and this behavior is a characteristic of $\mathrm{COHb}$ [14].

\section{Results and discussions}

\section{Case 1}

P.I., 30 years old, male. Police investigations revealed that he accidentally shot himself during hunting.

The external examination of the body revealed, at $3 \mathrm{~cm}$ external from the left medioclavicular line and $7 \mathrm{~cm}$ inferior and extern from the left nipple, an injury, considered to be the entrance wound, which consisted of a round-shaped, $3.2 \mathrm{~cm}$ diameter area, with lack of skin tissue, with discretely irregular margins, which interested the skin, the muscular layer and the underlying bony structure. The entrance wound was surrounded by a reddish excoriation, brown parchment-like, $0.7 \mathrm{~cm}$ wide, with blood infiltrated margins.

The toxicological analysis (fig. 1 and fig. 2) of the intercostal muscle fragment sampled from this injury revealed a $10 \% \mathrm{COHb}$ concentration.

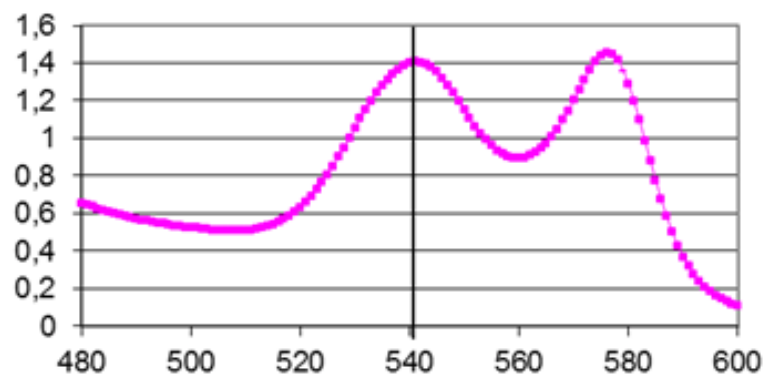

Fig. 1. Absorption spectrum of the unreduced blood sample, $\mathrm{COHb}=10 \%$

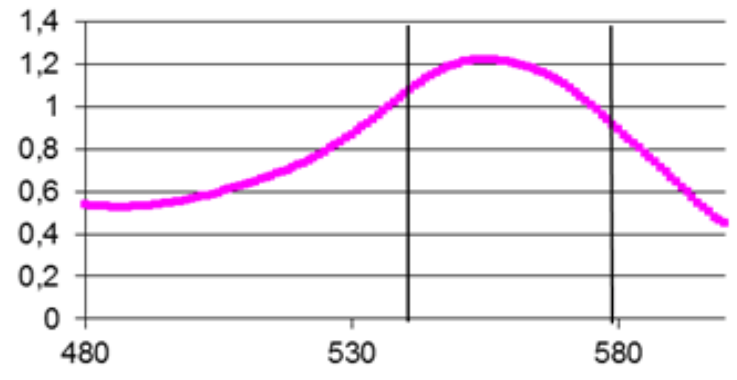

Fig. 2. Absorption spectrum of the reduced blood sample,

\section{Case 2}

S.Z., 20 years old, male. Found dead in a military compound where he performed his military service.

The external examination of the body revealed, on the anterior aspect of the left thorax, $2.5 \mathrm{~cm}$ internal from the left nipple, a slightly oval shaped wound, with diameters of $0.8 / 0.7 \mathrm{~cm}$, with slightly irregular margins, with lack of tissue, and surrounded by a contusion collar and a parchment-like collar; around it, a circular, brown-black, 5 $\mathrm{cm}$ wide area, with a darker discoloration in the lower part, and a discreet epidermal erosion with pink-violet shade in the upper part (entrance wound). On the lateral and posterior side of the left thorax, in the middle, there was a $0.6 \mathrm{~cm}$ diameter, circular wound with discreet blood infiltrates on the edges, slightly projected outwards, more so at the inner extremity (exit wound). The subjacent soft tissues of both wounds presented blood infiltrates. The blood infiltrates subjacent to the entrance wound had an intense red discoloration.

The toxicological analysis (fig. 3 and fig. 4) of the pectoral muscle fragment sampled from the entrance wound revealed a $60 \% \mathrm{COHb}$ concentration.

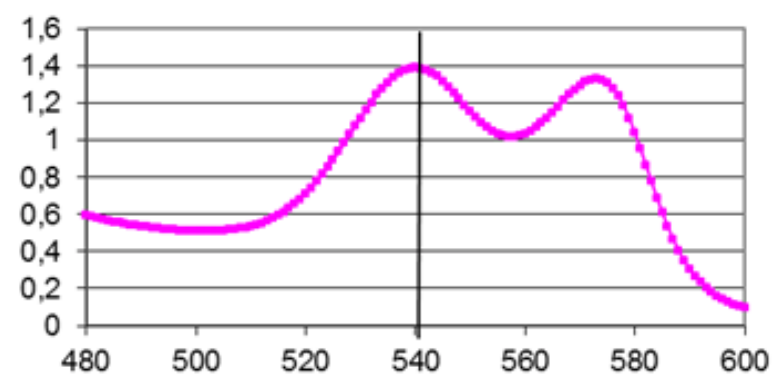

Fig. 3. Absorption spectrum of the unreduced blood sample, $\mathrm{COHb}=60 \%$

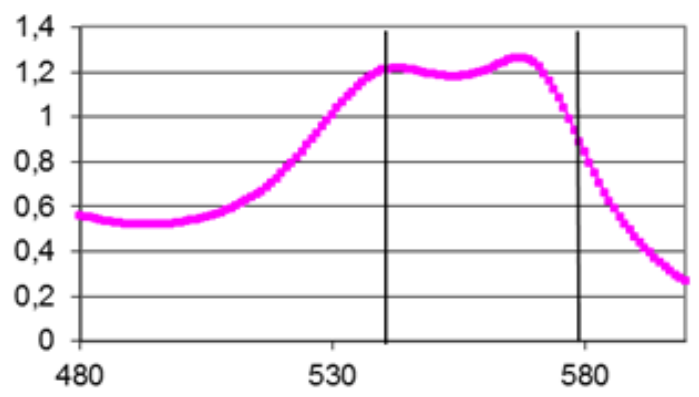

Fig. 4. Absorption spectrum of the reduced blood sample, $\mathrm{COHb}=60 \%$

\section{Case 3}

G.D., 44 years old, female. The police investigation showed that she was found dead at home.

The external examination of the body revealed, on the left thorax, in the precordial area, a $0.5 / 0.5 \mathrm{~cm}$ wound, with lack of tissue, surrounded by a $0.8 \mathrm{~cm}$ wide, parchment-like area, with black powder deposits. The subjacent intercostal muscles were blood infiltrated. The area was centered by a $0.5 \mathrm{~cm}$ round area with lack of tissue, located in the III-rd anterior left intercostal space. The surrounding muscle tissue was raspberry red.

The microscopic examination of the tissues sampled from the entrance wound revealed: deposits of black powder on the epidermis, thermal effect in the dermis, contusive effects (hemorrhagic infiltrates) in dermis and hypodermis (fig. 5).

The toxicological analysis (fig. 6 and fig. 7) of the intercostal muscle sample from the entrance wound revealed a concentration of $30 \% \mathrm{COHb}$. 


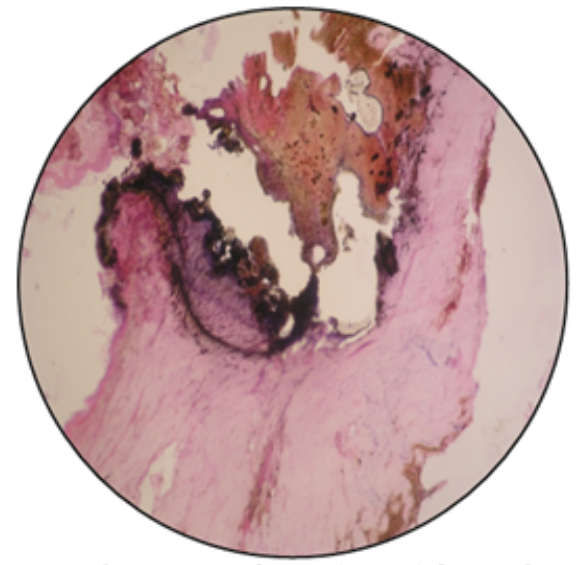

Fig. 5. Soot deposits on the surface of the epidermis, tissue sampled from the entrance wound, $\mathrm{HE}, 400 \mathrm{X}$

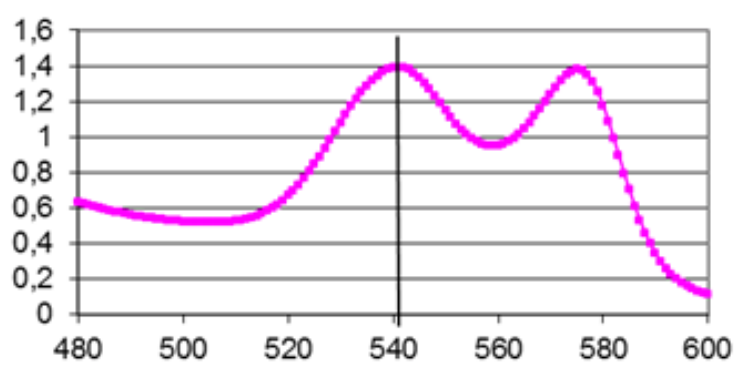

Fig. 6. Absorption spectrum of the unreduced blood sample, $\mathrm{COHb}=30 \%$

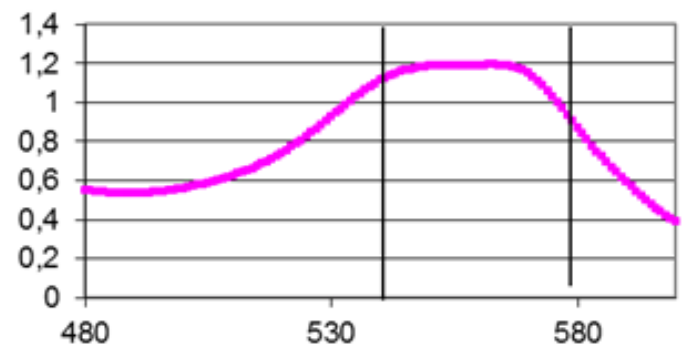

Fig. 7. Absorption spectrum of the reduced blood sample, $\mathrm{COHb}=30 \%$

\section{Case 4}

S.N.T., 39 years old, male. The police investigation showed that he was shot.

External examination of the body revealed, at $6.5 \mathrm{~cm}$ inferior and internal from the right nipple, a $1 / 0.7 \mathrm{~cm}$, oval wound, with lack of tissue and discretely irregular, brown, parchment-like margins; underlying, subcutaneous and muscular tissue infiltrated with blood. In the left lumbar area, a $0.8 / 0.4 \mathrm{~cm}$, parchment-like abrasion, on a $5 / 3 \mathrm{~cm}$ purple bruise background (blind exit wound).

The toxicological analysis of the muscle fragment sampled from the entrance wound revealed a $19 \% \mathrm{COHb}$ concentration. $\mathrm{A} 7 \% \mathrm{COHb}$ concentration was detected in the tissues sampled from the area where the bullet was found.

Establishing the direction of the shooting is perhaps the most important question to be answered by the forensic autopsy in gunshot victims. This implies the positive identification of the entrance and exit wounds. Only depending on their location and characteristics, experts can make assessments regarding the shooting direction and range, thus differentiating between the shooting from self-shooting. In all cases of close range shooting, a distinctive, raspberry red discoloration of the blood and soft tissues was noticed. In complex cases, in which we determined the $\mathrm{COHb}$ blood concentration by spectroscopy, in samples from the entrance wound, values between $10 \%$ and $60 \% \mathrm{COHb}$ were detected; these data were useful for the judicial investigation.

\section{Conclusions}

In gunshot cases in which establishing the diagnosis of entrance and exit wound based solely on morphological features is not possible, determining the blood $\mathrm{COHb}$ concentration in samples from both wounds can contribute to the clarification of this aspect.

In addition, due to the high $\mathrm{COHb}$ stability, we consider that this determination is also useful in case of decomposed bodies, where the aspect of the wounds is even more altered as the degree of putrefaction is more advanced.

Determining the $\mathrm{COHb}$ concentration in the blood sampled from tissues surrounding the entrance and exit wounds can be used for establishing the direction of the shooting, thus contributing to the juridical solidity of a gunshot incident file.

\section{References}

1. MORARU I, Medicina legala, Editura Medicalãa, Bucuresti, 1967, p 331-375.

2. OZSOY S., TUGCU H., The keyhole lesion, Rom J Leg Med, 24, 2016, p 257-260.

3. THALIA M.J., KNEUBUEHLB B.P., ZOLLINGERA U., DIRNHOFER R., A study of the morphology of gunshotentrance wounds, in connection with their dynamic creation, utilizing the 'skin-skull-brain model, Forensic Science International, 125, 2002, p 190-194.

4. WONG YS, KHAIRUL O, ATIAH AAG, ABDUL AZIZI, MUHD. HILMI B, NOOR HAZFALINDA H, SRI PAWITA ALBAKRI AH, Porcine Model: Differences in Entry and Exit Wounds by Semi-Automatic Pistol at Different Shooting Distances, Malaysian Journal of Forensic Sciences, 4(1), 2013, p 7-14.

5. AMADASI A, CERUTTI E, SPAGNOLI L, GIBELLI D, GORIO C AND CATTANEO C., The Difficult Task of Interpreting Cut Marks, Gunshot Wounds and Ligature Marks on the Skin: A Cautionary Note, Austin J Forensic Sci Criminol, 3(1), 2016, p 1047.

6. VERHOFF M. A., KARGER B., Atypical gunshot entrance wound and extensive backspatter, Int J Legal Med, 117, 2003, p 229-231.

7. DONOGHUE, E.R., KALELKAR M.B., RICHMOND J.M., TEAS S.S., Atypical gunshot wounds of entrance: an empirical study, J Forensic Sci, 29, 1984, p 379-388.

8. ENACHE A., Medicina legala, curs pentru studentii facultatilor de medicina. Editura Mirton, Timisoara 2005, p 151-158.

9. SAUKKO P, KNIGHT B., Knight's Forensic Pathology. 3rd Edition. Gunshot and explosion deaths. Edward Arnold Ltd. London. 2004, p 245-280.

10. MORONESCU M. Oxicarbonismul cronic în patologia internã. Editura Scrisul Romanesc. Craiova 1982, p 13-76.

11. DAVID S., KNIELING A., SCRIPCARU C., DIAC M., SANDU I., BULGARU ILIESCU D., Study of Carbon Monoxide Intoxication in Fire Victimis, Rev. Chim. (Bucharest), 68, no. 12, 2017, p 2932-2935.

12. PERJU DUMBRAVA D., RADU C.C., IOV T., DAMIAN S.I., SANDU I., TIMOFTE D., CHIROBAN O., An Unusual Case of Accidental Carbon Monoxide and Ethanol Intoxication in Two Commorientes Deaths, Rev.Chim. (Bucharest), 69, no. 7, 2018, p 1889-1891.

13. PROCKOP LD, CHICHKOVA RI. Carbon monoxide intoxication: an updated review. Journal of the Neurological Sciences 2007, 262, p 122-130.

14. BRUJA Z, IONESCU-VISAN I. Diagnosticul de laborator în intoxicabile acute, Editura Militara, Bucuresti, 1987, p 28.

Manuscript received: 27.11 .2018 